Corporate Social Responsibility in India - An Effort to Bridge the Welfare Gap

Jayati Sarkar and Subrata Sarkar

Indira Gandhi Institute of Development Research, Mumbai August 2015

http://www.igidr.ac.in/pdf/publication/WP-2015-023.pdf 


\title{
Corporate Social Responsibility in India - An Effort to Bridge the Welfare Gap
}

\author{
Jayati Sarkar and Subrata Sarkar \\ Indira Gandhi Institute of Development Research (IGIDR) \\ General Arun Kumar Vaidya Marg \\ Goregaon (E), Mumbai- 400065, INDIA \\ Email(corresponding author): ssarkar@igidr.ac.in
}

\begin{abstract}
Drawing on existing theoretical and empirical literature on the rationale behind Corporate Social Responsibility (CSR), this paper analyses the potential implications of mandated CSR under the recently enacted Companies Act, 2013 in India on firm incentives, likely responses of corporates that come under the ambit of the law, implications for resource availability and delivery of social goods, and the prospects and challenges of implementing mandated CSR. Insights into these issues are drawn by empirically examining the voluntary CSR behavior of a sample of 500 large companies listed on the Bombay Stock Exchange for the period 2003-2011 that predates the new regulation. The paper argues that notwithstanding the potential economic costs that may accompany mandated CSR, the provisions of the new Act are designed thoughtfully to balance the objectives of the corporation and its shareholders on the one hand and that of the society and its stakeholders on the other. However, addressing the challenges of implementation successfully would determine how far the objectives of the new regulations are met.
\end{abstract}

Keywords: Corporate social responsibility, firm incentives, social welfare, efficiency, regulation, enforecment

JEL Code: G38, H21, H53 L21

\section{Acknowledgements:}

Forthcoming in Review of Market Integration, 2015, Sage Publishers.

We thank the workshop participants at the Indira Gandhi Institute of Development Research for their comments and suggestions. We thank Ritika Jain for providing excellent research assistance. The usual disclaimer applies. A longer version of this work was written by the authors as a chapter in the India Development Report. 


\subsection{Introduction}

Indian corporations, like those in other countries, have had a long tradition of being engaged in social activities that have gone beyond meeting a corporation's immediate financial objectives. However, since the late nineties, CSR activities have increasingly come under the lens both of policy makers as well as of corporations' stakeholders as governance issues acquired increasing prominence. At the policy level, the formal focus on CSR started in India with the issuance of the Corporate Social Responsibility Voluntary Guidelines in 2009 by the Ministry of Corporate Affairs (MCA, 2009) that culminated in the enactment of Section 135 of the Companies Act 2013 (MCA, 2013) making CSR spending as well as CSR disclosure mandatory for specific types of companies. Significantly while CSR issues have been gaining in prominence across countries, India became the first country, and at the time this article is written, the only country to have made CSR activity mandatory for large and profitable companies incorporated into law. In all other countries CSR efforts by corporations have been kept largely voluntary, with only a select number of countries mandating corporations to disclose such activities.

Not surprisingly, therefore, Section 135 in India has generated largely polarized opinions among policy makers, corporates, industry associations, social sector organizations, and last but not the least, academicians. On one hand, the institution of mandatory CSR has been lauded in policy circles as a "historical opportunity" that could be a "game changer" for India where corporates would work hand in hand with the government and civil society to bring about "national regeneration" through sustainable development. Unorthodox as it may seem, some have argued that for a developing country like India, mandatory CSR may be an instrument to pursue a "middle path" between a liberal and a regulatory state so as to balance growth with social stability. On the other hand, critics of mandatory CSR, primarily corporates and business associations have pointed out that making CSR activities mandatory is essentially an exercise in outsourcing government social responsibility to the private sector and making the latter pay for the failures of the former. Further, when such activities are not clearly defined, mandatory CSR will create perverse incentives for corporates to camouflage activities to meet mandatory requirements or find ways to bypass the law.

Given the conflicting viewpoints around mandatory CSR, the objective of this paper is to examine in light of Section 135 and the Rules notified thereunder (MCA, 2014a), the 
fundamental and overarching question of whether mandated CSR would have the potential to bridge the welfare gap in a developing country like India. Specifically, the paper analyses the potential implications of Section 135 on firm incentives, the likely responses of corporates that come under this Section, its implications for resource availability and delivery of social goods, and finally the prospects and challenges of implementation of mandated CSR spending under the notified Rules. Insights into these issues are drawn by empirically examining the CSR behavior of a sample of 500 large companies listed on the Bombay Stock Exchange for the period 20032011.

The paper is organized as follows. Section 2 sets the stage for discussing the relevant issues outlined in the introduction by presenting the key provisions of mandatory CSR under Section 135 of the Companies Act, 2013. Section 3 provides an overview of the existing theoretical and empirical literature regarding the rationale behind CSR while Section 4 discusses the various regulatory approaches and identifies the potential costs and benefits of mandated CSR. To put the issue of mandatory CSR in perspective, Section 5 empirically analyses the voluntary CSR initiatives by the top 500 listed companies in India for the period 2003-2011, a period prior to the enactment of Section 135. Section 6 concludes the paper by examining the prospects and challenges of implementing mandatory CSR in India.

\section{CSR in India - The Legal Framework}

The first formal attempt by the Government of India to put the CSR issue on the table was in the issuance of Corporate Social Responsibility Voluntary Guidelines in 2009 by the Ministry of Corporate Affairs (MCA, 2009). Prior to this, the importance of CSR was discussed in the context of corporate governance reforms, such as in the Report of the Task Force on Corporate Excellence by the Ministry of Corporate Affairs (MCA, 2000). While the report made a business case for CSR as well as highlighted the social benefits stemming from it, the discussion was recommendatory in nature and there were little actionable points. It is in the Voluntary Guidelines of 2009 that the core elements of a CSR policy was spelt out that included care for all stakeholders, ethical functioning, respect for workers' rights and welfare, respect for human rights, respect for the environment and activities to promote social and inclusive development.

The Guidelines specifically drew a distinction between philanthropy and CSR activities, and highlighted the voluntary nature of CSR activities that go beyond any statutory or legal 
obligation. The Guidelines of 2009 were followed in 2011 by the National Voluntary Guidelines of Social, Environmental \& Economic Responsibilities of Business, also issued by the MCA (MCA, 2011). These guidelines were reportedly based on the inputs received from 'vital stakeholders' across the country and laid down nine principles for businesses to function in a responsible manner to promote inclusive economic growth at the national level. As in the case of the 2009 Guidelines, the 2011 Guidelines were voluntary in scope wherein corporates were urged to adopt all the nine principles, and to report their adherence to the guidelines based on an 'apply-or-explain' principle. Interestingly, while one of the implementation strategies suggested in the 2009 Guidelines was to earmark "specific amount related to profits after tax, cost of planned CSR activities, or any other suitable parameter," no such suggestion was included in the 2011 Guidelines.

The transition from a voluntary CSR regime to a regulated regime came when the Securities Exchange Board of India (SEBI) required the top listed 100 companies, as part of Clause 55 of the Listing Agreement, to mandatorily disclose their CSR activities in the Business Responsibility Reports (BR Reports) accompanying the Annual Reports. This, SEBI opined was in the larger interest of public disclosure and represented a move towards integrating social responsibility with corporate governance. The most ambitious attempt at mandated CSR activities for companies came with the enactment of Section 135 of the Companies Act 2013 (MCA, 2013). As stated in the introduction, Section 135 made CSR spending as well as reporting mandatory for the very first time in India and brought the CSR activities of Indian corporates under the purview of corporate law. Specifically, the provisions under Section 135 requires companies with net worth of rupees five hundred crore or more, or turnover of rupees one thousand crore or more or a net profit of rupees five crore or more (i) to appoint a CSR Committee of at least 3 directors (one independent director), and (ii) under the guidance of the CSR Committee, spend in every financial year, at least two per cent of the average net profits of the company made during the three immediately preceding financial years, in pursuance of its Corporate Social Responsibility Policy. While the quantum of CSR spending along with reporting has been mandatorily set under Section 135, there is some inbuilt flexibility in the law in terms of a company's choice of its CSR activities. Instead of rigidly defining the boundaries of CSR, the act broadly specifies in Annexure VII of the Act, the scope of social responsibility in terms of a list of activities that the corporate can potentially undertake, leaving the choice of 
activities to its discretion. So far as compliance to Section 135 is concerned, the law adopts a comply-or-explain approach, with no explicit penalties for non-compliance.

Subsequent to the passage of the Act, the Ministry of Corporate Affairs notified the Rules with respect to CSR on February 27, 2014. Apart from listing out specific activities on which the companies are free to spend the amount earmarked under their CSR Policy. The Rules guard against self-serving expenditure by companies by specifying that CSR activities that benefit only the employees of the company and their families shall not be considered as CSR spending under the provisions. However, companies may build CSR capacities of their own employees through reputed institutions with the proviso that such expenditure cannot exceed five percent of the total CSR expenditure made by the company in that financial year. The Rules framed under Section 135 of the Act, came into force from April 1, 2014.

With the enactment of Section 135 of the Companies Act, 2013, as observed by the Ministry of Corporate Affairs in the Report on the Standing Committee on Finance (LSS, 2010), India became the first country to include provisions on CSR in Company Law and make CSR expenditure mandatory for corporates based on pre-specified criteria. In the rest of the world, however, CSR is still a voluntary exercise left to the discretion of the corporates. What is mandatory at most is the compulsory reporting of CSR activities undertaken by corporates in a growing number of countries, although this too is not the case across all countries. Thus, in countries such as Sweden, Norway, the Netherlands, Denmark, France, Australia and China, either government regulations or stock exchange regulations or both require corporates to disclose their CSR activities through sustainability reporting. ${ }^{1}$ The distinguishing feature of Section 135 is that it not only makes the reporting of CSR activities mandatory, but goes a step further to mandate CSR activities in the first place.

\section{Why Corporate Social Responsibility?}

In any CSR discussion it is important to understand why corporates should be socially responsible in the first place? Why, instead, would corporates not go about their business of shareholder value maximization, and leave the task of pursuing social development to

\footnotetext{
${ }^{1}$ For details of relevant reporting requirements for thirty countries, see KPMG- UNEP (2010).
} 
government agencies? What is the underlying rationale of CSR, and more specifically, in the context of Section 135, the economics of mandatory CSR? The question of "why CSR" can be essentially decomposed into three sub-queries namely, what is CSR, what is the rationale for CSR, and what is the rationale for mandated CSR.

\subsection{Defining CSR}

The dilemma on the relevance of CSR in corporate activity is inextricably linked with defining the scope of CSR for a corporation. A review of the existing literature on CSR reveals that there is a diversity of opinions and ambiguity on the elements that constitute socially responsible behavior on the part of corporates. ${ }^{2}$ Arriving at an agreed-upon definitional construct for CSR is important, first from the point of view of the entity which is responsible for CSR, i.e., the corporation, and second from the point of view of the entity that is impacted by CSR, i.e., the society at large, and finally from point of view of the entity that seeks to connect the firm and society, i.e., the regulator. In any national context, the debate on the extent to which CSR activities should be regulated should at least begin with a consensus among these three entities on what constitutes CSR.

The definition of CSR has evolved over the years. A sample of such definitions found in the academic literature and those advocated by international agencies are provided in Box 1 . Country-specific perspectives on CSR including India are provided in Box 2. As is evident from the two Boxes, CSR has been conceptualized in terms of a wide range of corporate behavior, starting at one extreme with the maximization of shareholder profits within the rules of the game (Friedman, 1970) to the other extreme of an all-encompassing objective of balancing economic, social and environmental objectives to serve shareholder and stakeholder interests as defined by UNIDO, World Bank and the World Business Council for Sustainable Development (WBCSD). The notion of CSR in-built in most of these definitions is that CSR is essentially a voluntary activity that serves as a bridge between the corporation and the society, with the goal of the corporation re-defined from maximising only shareholder interests (the shareholder primacy view) to the interests of all its stakeholders. Closely related to this is the focus on balancing economic objectives with social and environmental objectives that could in the process compel

\footnotetext{
${ }^{2}$ Reinhardt et al. (2008) observe that given a "bewildering" array of CSR definitions and conceptualizations in the literature, the challenge is to identify a "consistent and sensible definition."
} 
corporations to sacrifice profits in the interest of society. Ethical and moral behavior, and activities pursued beyond regulatory and legal compliance that contribute to social welfare also fall under the ambit of CSR activities.

There is a growing recognition among researchers and policy makers that CSR issues in developing and emerging countries like India are somewhat distinct from those in developed countries. Social, environmental and sustainability problems are more acute in developing countries, especially those impacted by globalization, economic growth, investment and burgeoning economic activity (Visser, 2007). Further, as Amaeshi et al. (2006) point out in the context of Nigeria, CSR in low income countries are predominantly focused on socio-economic issues of poverty alleviation, health-care provision, promoting education and infrastructure development, in contrast to the CSR priorities in Western countries such as issues related to business ethics, fair trade, green marketing, climate change and socially responsible investments. Likewise, the domain of CSR in India as outlined in several public policy documents as well as in the initiatives of corporates and various industry associations is defined around socioeconomic activities geared towards meeting the development goals of the country, while not necessarily sacrificing the economic objectives of the corporates.

\subsection{The Rationale of CSR}

To understand better the drivers of CSR in developing countries and the considerations that have possibly dictated the imposition of mandatory CSR in India, it is important to highlight the pros and cons of socially responsible activities from the viewpoint of both the society and the corporation along with the need for regulatory oversight of such activities.

\section{CSR and Social Welfare}

At the societal level, there has been an increasing recognition that the economic activity of a corporation needs to be embedded in societal concerns. In fact, much of the discourse on CSR is conducted in terms of the relationship between business and society, of the moral and ethical imperative of business that goes beyond legal compliance, to contribute positively to society. Bowen (1953), among the first academicians to draw attention to the social responsibility of corporations, argued that private corporations should be evaluated purely in terms of its "demonstrable contribution to the general welfare" (p.52) in terms of the production of social goods such as higher standards of living, and in spreading economic progress and security, and 
that the survival of the free enterprise system critically depended on such contributions. A similar argument was forwarded by Steiner (1971) who argued that while businesses are primarily economic institutions, they are also expected to contribute towards achieving social goals, and such responsibilities should increase with the size of the business. This line of thinking, evolved over the years culminating in the stakeholder perspective that argues that a corporation's goal should go beyond maximising profits for its shareholders, and should instead be defined with respect to all its stakeholders (customers, suppliers, employees, community, etc.) including the society at large (Freeman, 1984).

While much of the argument for CSR from the perspective of the society is ensconced in moral and ethical considerations, there are economic arguments too that have been made for and against CSR. The strongest position taken against firms engaging in CSR has been taken by Friedman (1970) who argued that it would be socially irresponsible for profit maximizing firms to engage in CSR; any diversion of funds to create social good at the cost of shareholder returns would be tantamount to 'theft.' The implication of Friedman's thesis is that CSR would lead to allocative inefficiencies and social losses. On the other hand, a body of theoretical research has provided the economic rationale for the social role of private firms in the provision of public goods via CSR. For instance, Besley and Ghatak (2007), based on a theoretical model argue that CSR is no different from the private provisioning of public goods, that it can be Pareto improving and that, CSR by private-for-profit firms will be potentially efficient when provisioning of public goods by governments is sub-optimal.

The rationale for CSR in the case of developing countries extends beyond standard arguments as highlighted above and explicitly brings in the role that CSR can play in meeting developmental objectives of poverty reduction and inclusive growth. To begin with, there is no place for Friedman's view of CSR. Instead, the social role of the corporates in development vis-à-vis that of the government becomes an integral part of the discourse. In particular, CSR contributes to governmental resources and delivery mechanisms either to supplement these, i.e., to chip in, or as a substitute, to fill up "governance gaps" especially where governments are weak, corrupt and under-resourced, and institutions are weak (Visser, 2008; Blowfeld and Fyrnas, 2005; Matten and Moon, 2008). These arguments closely mirror the conclusions arrived at by Besley and 
Ghatak of the role of CSR where government provisioning could be sub-optimal for a variety of reasons.

\section{CSR and the Firm}

Turning to the rationale of CSR from the perspective of a firm, two distinct motivations are identified, one which is 'performance driven' and the other which is 'stakeholder-oriented' (Basu and Palazzo, 2008, cited in van der Wees, 2009). ${ }^{3}$ Performance driven CSR is strategic in nature whereby firms incurring CSR expenses are driven by the profit motive and the belief that corporate social performance will translate into corporate financial performance in the long run. This is essentially the business case for CSR where expending on CSR is perfectly consistent with shareholder wealth maximization, with no trade-off between shareholder objectives and social responsibility. ${ }^{4}$ The premise underlying the business case for CSR is that "smart companies are those that will take a proactive approach and see CSR as a feature of mainstream business practice, employee engagement and a competitive advantage" (Davies, 2002). In other words, it pays to do CSR.

Stakeholder-oriented CSR is driven by the motivational desire of the firm to serve the interests of all stakeholders of the corporations beyond those of its shareholders. While the shareholder primacy view predominantly focuses on the profit motive, the stakeholder perspective is seen as reconciling the social and economic goals of an organization driven by a moral motive of serving the interests of the society at large (van der Wees, 2009). Many a times, a corporation's motivation to serve stakeholder interests through CSR, are a reaction to pressures exerted from stakeholders at large (Frynas, 2005). Whatever the case, stakeholder oriented CSR activities entail a trade-off with profit maximization, which Elhauge (2005) refers to as "sacrificing corporate profits in public interest."

However, critics of the stakeholder perspective of CSR argue that stakeholder value maximization is inconsistent with the efficient operation of the company. Multiple objectives that the stakeholder theory envisages distorts managerial incentives as it is not clear what the manager should maximize as maximization requires a single valued function. What will be the

\footnotetext{
${ }^{3}$ Basu and Palazzo mention a third driver, 'motivational' but the theory here is not very well developed.

4 "a happy convergence between what your shareholders want and what is best for millions of people the world over" (Annan, 2001).
} 
weights on the different objectives of the different types of stakeholders and who will determine them? In the absence of a clear-cut economic rationale to undertake such an exercise, responsible behavior towards stakeholders can actually lead managers to behave irresponsibly as managers may strategically use stakeholders' value maximization and CSR engagement as a camouflage for personal gains.

Firm-level motivations to engage in CSR acquire additional dimensions in developing countries like India. As Visser (2008) notes, with the advent of globalization, the need to access international markets could drive developing country firms to engage in CSR consistent with globally accepted norms. This is especially the case with respect to meeting environmental standards and signaling the same through sustainability performance reporting and compliance to CSR codes (Visser, 2005). International exposure through the listing or operations of multinational companies have also been creating pressures to comply with various forms of sustainability performance reporting and CSR code compliance such as those with respect to ethical trading initiatives, fair trade practices, and product labeling.

\section{Regulatory Approaches to CSR}

The regulatory approaches entail the extent to which the government influences CSR behavior of firms in two respects, first with respect to reporting of CSR activity, and second with respect to the amount of spending for CSR activity. Based on this, one gets three types of regulatory regimes, namely (i) voluntary reporting and voluntary spending (ii) mandatory reporting but voluntary spending, and (iii) mandatory reporting and mandatory spending. Much of the policy debates around the world is with respect to whether CSR reporting should be voluntary or mandatory i.e., whether firms should be required by laws and regulations to report their CSR activities. In comparison, the debate on voluntary versus mandatory spending is moot in most countries given that CSR activities, howsoever defined, is voluntary in nature (Box 1).

\subsection{Mandating CSR disclosure}

The issue of mandating CSR essentially pertains to the question of whether corporations are required by laws and regulations to report/disclose its CSR activities or whether the decision to report is to be left to the business judgment of the corporation. The issue of mandatory CSR reporting has gained prominence in recent years following the global financial and economic 
crisis in the 2000s, a string of corporate misconduct and failures, and growing threats from business operations to environmental sustainability from business operations, all of which have created a 'trust deficit' between corporates and their stakeholders (KPMG-UNEP, 2010). Consequently, CSR governance has over time shifted from a "hands-off" approach to more stringent regulation in terms of imposing greater mandatory disclosure requirements regarding how CSR by corporations are impacting its different stakeholders and the community at large.

The economic rationale for mandatory CSR disclosure vis-à-vis voluntary disclosure is not $a$ priori obvious. If CSR at the firm level is driven by strategic considerations or to serve the interest of stakeholders, then one can argue that it is in the self-interest of a firm to voluntarily disclose its CSR activities. In other words, if it pays to engage in CSR, it pays to disclose. In fact, corporate responsibility reporting is considered to have become the "de facto" law for business (KPMG, 2011) essentially because corporations have increasingly realized that CSR reporting positively impacts financial value. Not reporting on the other hand is likely to adversely affect competitiveness, cost and new business opportunities. Under voluntary reporting, if all firms engaging in CSR report in equilibrium, making CSR reporting mandatory will add to regulatory burden without adding any additional information (Lin, 2010). Further, mandatory CSR reporting could have a perverse effect on corporate accountability if it leads to useless and biased information (Hess and Dunfee, 2007).

From a public policy perspective, the need for mandatory reporting arises in all probability when corporations do not view CSR as a paying proposition where social performance does not translate into financial performance at least in the short run, yet CSR is perceived to be beneficial at the societal level. If CSR is socially valued, mandatory reporting is more likely to evoke a positive CSR response whereas in case of voluntary reporting, CSR could be theoretically zero in the limit. Further, mandatory reporting could reduce information asymmetries especially in emerging markets with imperfect capital markets and is "critical" for engaging with stakeholders and in ensuring corporate accountability (Hung et al., 2013). Finally, in countries with weak institutions and enforcement, mandatory CSR reporting can prevent several social bads that are not internalized by existing laws and regulations. That mandatory CSR disclosure has many takers despite its critics is evident from the fact that since the early 2000s, governments and 
stock exchanges through laws and regulations have progressively mandated CSR disclosures by corporations without impairing in any way the voluntary nature of CSR activities .

The transition from a voluntary to a mandatory regime with respect to CSR reporting is most evident in the Indian scenario. Disclosure of CSR activities in the country have moved from being purely voluntary prior to 2012, aided by reporting frameworks suggested by the Government through the issuance of the Voluntary Guidelines of 2009 and 2011, to being mandated through since 2012 by the Securities and Exchange Board requiring top 100 companies to file Business Responsibility Reports, to being mandated for a much larger set of listed and non-listed companies under Section 135 of the Companies Act, 2013.

\subsection{Mandating CSR Spending}

The definitions of CSR as presented in the literature and the theories of CSR that underline the rationale for corporates to act in a socially responsible manner, howsoever conceptualized, largely views CSR as voluntary in nature. A corporation decides its optimal CSR as part of its business strategy and subject to market pressures. Such market pressures can emanate from market players, namely, consumers and investors, and from stakeholders and civil society organizations. The government's role in such a scenario is seen to be only limited to endorsing, facilitating and partnering socially responsible behavior of corporates through policy instruments such as tax exemptions for CSR activities, through award schemes and facilitating information dissemination and training, guiding corporates to adopt and implement CSR best practices through standard setting, issuance of voluntary guidelines and certification systems, and forging partnerships with the private sector to promote and execute the CSR agenda including public good provisioning to meet developmental objectives.

Economists and policy analysts have been generally cautious on the issue of whether companies should be mandated to spend resources on CSR activities. At the very basic, economic efficiency dictates that CSR should be kept voluntary and companies would undertake it if the perceived benefits at the margin outweigh the opportunity cost and thereby adds value to the company. It is in this spirit, that countries in general have avoided regulating CSR through mandated spending, and instead have chosen to influence CSR activity through mandatory reporting of such activities, leaving the decision to engage in socially responsible activities to the discretion of the corporation and the forces of the market. As Gangopadhyay (2012; 2014) opines, mandated CSR 
has no place in a market driven society. Mandated CSR spending is also seen as an implicit corporate tax which would add to the already high tax burden on corporates and reduce the global competitiveness of Indian companies, and that companies for which CSR makes good business sense would undertake such expenditure anyway, mandated or not (Gangopadhyay, 2012; Karnani, 2013). With regard to the latter, Gangopadhyay (2012) argues, similar in spirit to the debate between voluntary and mandatory disclosure that if CSR makes good business sense and the market values it, then managers would build in the optimal level of CSR in their business strategy to signal to the market the social contribution of their companies in line with shareholder expectations. Further, if all firms, efficient and inefficient were undertaking CSR to the same extent, the information content of CSR will become weak and the market will be unable to distinguish the efficient firms from the inefficient ones. Mandated CSR, rather than been seen as filling in governance gaps, is also seen as the abdication of government's responsibility in providing public goods to meet development goals based on "democratically determined priorities" (Karnani, 2013).

The preceding discussion on the regulatory approach to CSR with special reference to India shows that since the year 2008, in a span of just five years, India has transited from a regime of CSR being a purely voluntary activity with voluntary reporting, to a CSR regime of voluntary activity with mandatory reporting (years 2012) to a regime of mandatory activity with mandatory reporting (year 2013). In the earlier years firm level CSR decisions were primarily determined by market pressures from consumers, investors, stakeholders and civil society organizations with the government playing the role of a facilitator through information dissemination, issuance of CSR guidelines, encouraging dialogue and fostering public-private partnerships. In the latter years, pursuant to Section 135, the Government has assumed a more proactive and direct role by making CSR reporting and CSR spending mandatory for all firms. The latter role of the government is increasingly in line with the more involved role that states are taking in guiding CSR in emerging economies such as China (Ho, 2013). 


\section{CSR Practices of Indian Companies}

Given that Section 135 has been enacted and Rules for its implementation are in place, an evaluation of its prospects would have to be based on an understanding of the CSR behavior of Indian corporates in the pre-enactment period. While company level case studies on CSR abound, large sample studies are relatively few and are mainly cross-sectional in nature. This section supplements the existing analyses by empirically examining the CSR behavior of a panel of top 500 listed Indian corporates - based on March 2008 market capitalization - over a period of nine years, 2003-2011. The CSR analysis presented is based on a content analysis of the information contained in the Annual Reports of these companies. The content analysis involved identifying whether a corporate disclosed undertaking any CSR activity, and if so, the type of CSR engagement, and the amount spent on CSR. Referring to the discussion of the evolution of the regulatory framework in the preceding sections, it is apparent that the period of analysis chosen for the analysis coincides with the period when both CSR spending and CSR disclosures were voluntary. Thus, the CSR behavior of firms would reflect their true incentives to engage in CSR activities.

Turning to the first question of the incidence of CSR, Figure 1 presents the year-wise percentage of listed corporates in the study sample that have voluntarily adopted CSR and reported it. The striking feature of the figure is that the percentage of large listed companies that have engaged and reported CSR has steeply risen from just around 7 per cent to a high of around 62 per cent. Additionally, there has been a secular increase in the incidence of CSR, particularly in the early years of the period when there were no pro-active CSR policy of the government, with the upward trend continuing post 2009 after the first set of voluntary guidelines was issued and CSR was formally introduced in the Companies Bill, 2009 and publicly debated. It is therefore reasonable to conclude that the increased incidence of CSR among the top firms was in response to pressures from the "market for virtue" (Vogel, **) with strategic considerations discussed earlier, influencing a growing proportion of firms to signal to the market their CSR engagement with the expectation of reaping reputational and financial benefits.

A logical question that follows from Figure 1 is which types of firms have sought to engage in CSR? Table 1 compares the average company characteristics of sample firms which report CSR in their Annual Reports and those that do not. The characteristics are defined with respect to 
networth, sales, profit after tax and age. The first three characteristics have been used as alternative criteria for the application of Section 135. As is evident from the estimates in the Table, the mean and median net worth and sales of companies which report CSR are significantly higher than those that do not report CSR. In fact, the mean networth and sales of those disclosing CSR are more than double of those that do not disclose indicating that on an average, size matters in CSR engagement. Going by the criteria set under Section 135, the average size of firms not engaging in CSR (net worth of Rs. 6396 crore and turnover of Rs. 9687 crore), are much higher than the minimum size that would come under the CSR net (Rs. 500 crore and Rs. 1000 crore), and the median net profits of those not reporting CSR, of Rs. 933 crore are way above, 180 times higher than, the profit threshold of just Rs. 5 crore stipulated in the Section. These estimates indicate that although the proportion of companies voluntarily undertaking CSR is increasing over the years, the relatively low thresholds specified under Section 135 will bring in a large chunk of the top listed companies under its purview. This contention is further supported by an analysis of the CSR spending of 27 top corporates for the financial year 2012-13, as presented in Table 2. As is evident from the figures of total turnover and PAT of the companies in the Table, all of the 27 companies would come under the purview of Section 135. Yet more than half of the companies have been spending less than 2 per cent on CSR, and 11 of the 27 companies even spending less than one per cent. Interestingly, the PAT of all the companies in the list are several multiples of the Rs.5 crore, ranging approximately between Rs. 300 crore and Rs. 21,000 crore.

Turning to the types of CSR activities that companies have reported, Table 3 and Figure 2 present respectively the nature of CSR activities that companies have chosen to engage in, and the variety of their CSR engagement. As Table 3 shows, considering the distribution across all activities reported over the nine years of the sample, the CSR activities in the areas of food, drinking water, sanitation and health as well as involvement in education, skill development/training and employment comprise of the major chunk of corporate sector engagement in the social sector, each accounting for around 17 per cent of the total activities reported. Energy/sustainability and environmental issues also feature prominent among the CSR initiatives. These are followed by CSR through providing support to NGOs and working for the disadvantaged sections of society. CSR on Table 3 clearly reveals that corporates have been 
voluntarily and predominantly engaging in social activities that broadly conform to the CSR objectives of the Government as enlisted in Annexure VII of the Companies Act 2013. It also reveals that CSR behavior of large Indian corporates see themselves in the role of supplementing governmental efforts in public good provisioning to meet the developmental objectives of the country.

The distribution of companies by the number of distinct CSR activities they engage in is presented in Figure 2. As is evident from the Figure, companies choose to focus on a small number of CSR activities with one third of companies focusing on only one activity and around 78 per cent of companies engaging in 3 or lesser number of activities. The estimates show that companies avoid spreading themselves too thin, and perhaps choose activities which are built around their core business activities.

To examine further the strategic motives of Indian companies in engaging in CSR, the data is analyzed to probe for evidence on 'green washing,' a practice by which companies whose business operations negatively impact the community, compensate for such consequences by undertaking CSR. As is widely recognized among policy makers and academia, companies that do more "harm" are also likelyto do more "good" to offset corporate social irresponsibility with corporate social responsibility (Kotchen and Moon, 2012). This is especially relevant with respect to environmental issues where polluting industries proactively build in CSR as part of corporate strategy to maintain its reputation and value.

In India, seventeen industries have been identified by the Central Pollution Control Board as the most polluting industries. ${ }^{5}$ Based on this classification, companies in the sample are divided into those belonging to polluting and non-polluting industries. In every year, about 20 per cent of the sample companies come from polluting industries. For each group, the percentage of companies which reported CSR is computed and the year-wise results are depicted in Figure 3. The figure clearly indicates that in the initial years a significantly higher proportion of companies in polluting industries have been undertaking CSR activities compared to those in non-polluting

\footnotetext{
${ }^{5}$ These are Aluminium Smelter, Caustic Soda, Cement, Copper Smelter, Distilleries, Dyes \& Dye Intermediates, Fertiliser, Integrated Iron \& Steel, Tanneries, Pesticides, Petrochemicals, Drugs \& Pharmaceuticals, Pulp \& Paper, Oil Refineries, Sugar, Thermal Power Plants, and Zinc Smelter.
} 
industries. There is some evidence of green-washing based on this elementary measure. However, over the years, CSR activities by companies in non-polluting industries have risen at a faster rate, perhaps in recognition that CSR-spending makes business sense, and accordingly the difference in the incidence of CSR activities between polluting and non-polluting industries have progressively narrowed. In fact there is no noticeable difference in CSR incidence between these two groups in the last two years of our sample. With the new provisions of the Section 135, this scenario will continue as all companies, except for size considerations, will be required to carry out CSR activities.

Does CSR help companies, does it make business sense? Examining the empirical evidence on the relationship between corporate social performance and corporate financial performance, a meta-analysis of 122 empirical studies conducted up to 2001, mostly with respect to the US, concludes that there is predominant evidence of a positive association between a company's social performance and its financial performance (Margolis and Walsh, 2003) ${ }^{6}$. With regard to developing countries, the number of empirical studies is too few to derive any definitive conclusions. A couple of existing studies with respect to Thailand (Connelly and Limpaphayon, 2004) and India (Mishra and Suar, 2010) does, however, show that CSR has a positive effect on firm valuation.

Analyzing the relationship between reported CSR and financial performance for the sample under consideration, Table 4 reports the mean and median values of two profitability indicators namely return on assets (ROA) and return on sales (ROS), and two market performance indicators namely price to book (PB) and price to earnings (PE) for companies undertaking CSR and those who are not. The Table indicates that though there is no significant difference between the profitability measures between these two groups of companies, the value of both the market indicators are higher for companies undertaking CSR. This difference holds up statistically as is evidenced by the Wilcoxon test and the t-test for equality median and mean respectively. A stronger confirmation of the above observations is obtained by estimating a simple regression model of return-on-assets and price-to-book on the dummy variable CSR and age, with the later acting as a control variable to proxy for different aspects of firm size (profit, turnover and net-

\footnotetext{
${ }^{6}$ A similar conclusion is arrived at by Heal (2008).
} 
worth). The coefficient on the CSR variable is significant at less than 5 percent level in both regressions (Tables 5A and 5B). Undertaking CSR increases price-to-book by 0.4, while it increase return-on-assets by 1.2 percent. The age variable is negative and significant suggesting that the younger and the newer companies are valued more in the market, possibly because of their higher growth potential.

The results make intuitive sense. CSR activities may lead to temporary reduction in short term accounting profit, but may create market value in the long run. The stock market may reward companies with virtue and ethics leading to lowering of cost of capital and ultimately to higher valuation of the company. Admittedly, these regression results need to be further tested within a more elaborately specified empirical model, but the initial statistical tests do suggest a strong link between CSR and company performance, both in accounting and market measures.

Finally, to get a perspective on the extent to which mandatory CSR in India can supplement government resources to fill the 'welfare gap,' the CSR criterion under Section 135 is applied to an almost exhaustive set of listed companies in 2012 as covered by the Prowess database and the total funds that can be potentially spent on social programs, computed. Considering a sample of 5138 listed companies covered by Prowess, the three alternative criteria based on net worth, turnover and PAT is applied to find out the number of companies that would have come under the purview of Section 135, had it been applied in the years 2010, 2011 and 2012. The respective numbers as shown in Table 6 are 1500, 1409 and 1372. On further screening out companies with non-positive PAT, the resulting set of companies on which the 2 per cent CSR could have been levied are 1457, 1312 and 1265 for the three years considered. The total estimated CSR spending on qualifying companies with positive PAT thus obtained for the years 2010-2012 are respectively Rs. 7609 crore, Rs. 7670 crore and Rs. 8344 crore. The final step in the exercise is in comparing for each year, the (potential) resources mobilized from corporates through CSR to the total social expenditure of the Central and State Governments. The percentages computed (Table 6) show that the argument that the new CSR provisions are away of government abrogating its responsibility to the private sector is not very strong. The estimated total CSR spending is less than 2 per cent of total government social expenditure. Going by these estimates, 
the mandatory CSR provision seems to be more about the idea of instilling "the spirit of CSR amongst corporate sector."

\section{Mandatory CSR: Prospects and Challenges}

The empirical analysis in the preceding section reveals that Indian corporates even prior to the enactment of mandatory CSR under Section 135 of the Companies Act 2013 have steadily acquired the mantle of being socially responsible as is evident from a manifold increase in the proportion of companies reporting their CSR activities over the years. This upward trend has taken place in a regime where both CSR spending and reporting were voluntary, indicating that there is a strong business case for companies to be socially responsible. This is borne by the result, albeit preliminary, of a positive relationship between CSR and firm performance, as measured by ROA and market value. Similar to the overwhelming evidence existing in the context of developed countries, the analysis of the top 500 companies in India does show that a firm's social engagement is being positively valued in the market. In light of these findings, it is important to address the prospects and challenges associated with Section 135 in the near future.

\subsection{The Prospects}

Mandated CSR has its proponents and opponents. While the proponents believe that the objectives of the corporation should go beyond profits and shareholders and extend to social welfare and all stakeholders, opponents argue that corporations have well defined role of maximizing shareholder value and therefore CSR should be market driven and left to the their discretion. This is a debate on normative issues and is difficult to resolve easily. Any economic policy has gainers and losers and a "good" policy tries to balance the gains against the losses. While the new provisions of Section 135 will certainly lead to an increase in the amount of CSR spending by Indian companies manifold compared to their existing level, it does recognize that mandated CSR may impose some economic costs on these companies and its shareholders. Accordingly the provisions of section 135 try to provide a number of flexibilities to ensure that these costs CSR do not hurt the companies and their shareholders disproportionately to substantially reduce the net social welfare gain. 
A systematic evaluation of the arguments both for and against mandated CSR seem to suggest that the new CSR rules framed under Section 135 are conceptually strong and well laid out. First, under the current rules, CSR expenditure is a utilization of profit and avoids the relevant issue of multiple objectives inherent in the stakeholder theory. Companies will still have shareholder value maximization as a single objective from which, ex post, two per cent of the profits can be appropriated towards the CSR activities. Thus the current CSR stipulations do not distort economic objectives as is typically the case with stakeholder optimization.

Second, the amount of two per cent of PAT is not a huge demand on corporate resources. For example, when one considers the median PAT and the median turnover of the top 500 companies (Table 1), the 2 per cent rule will warrant a spending of Rs. 4.65 crore on CSR which seems to be quite modest when judged by the turnover of Rs. 9687 crore. Considering all listed companies that would come under the CSR rule, the company with the median PAT would be required to spend Rs. 55 lakh annually as of 2012 (Table 7). These figures also raise doubt that CSR spending is likely to result in significant loss of competitive advantage either in the domestic or in the international market, at least for the top 500 companies. In fact if there is a business case for CSR, which empirical evidence tend to support, then international companies may also be doing CSR to gain, rather than lose, competitive advantages,

Third, the CSR rules adopt a "comply or explain" approach rather than a "comply or else" approach thus leaving room for companies to assess the opportunity cost of CSR. Smaller companies i.e., those below the specified thresholds, for which the opportunity cost of internal capital is likely to be high are exempt from CSR in the first place. Furthermore, a company which determines that CSR spending of 2 percent may not be in its best interest may not spend or spend less than the required amount provided its explanation is acceptable by the regulator. In this regard, the position taken by the MCA is instructive. In response to a query from the Parliamentary Standing Committee on the Companies Bill 2009 with regard to the government monitoring of CSR activities under the proposed rule, the Ministry spokesperson replied that the "whole emphasis" of the Act was to require companies to disclose their CSR related activities in the public domain so that anybody, including the Ministry can monitor. However, there would be no formal oversight mechanism by which the Government will independently monitor a 
company's CSR activity. ${ }^{7}$ Going by this position, the expectation therefore is that by creating a social mandate through the law and thereby building up social expectations, mandated spending, with justifications for exceptions, is likely to generate more CSR spending than voluntary spending with mandated reporting.

Fourth, companies which feel that they do not have adequate expertise or core competency to carry out CSR related projects may either appoint reputed trusts to carry out the projects, or simply donate the specified amount to the Prime Minter's Relief Fund. In this context, it is to be noted that a large number of companies are undertaking CSR voluntarily, some to the tune of $6 \%$ of their PAT, much before the regulations came into effect. These companies must be assessing that the benefits of CSR outweigh the costs of doing so. Some of these companies which run very complex operations around the globe must have found CSR well within their core competency.

Finally, what about the concern that mandated CSR might reduce the spending by some companies who are voluntarily spending more than two percent of their net profits, since the signaling value of CSR would reduce when all companies are made to spend on CSR. While this argument does have some merit, it is also possible that the CSR spending of these firms might actually increase to preserve the signaling value of CSR and it essentially becomes an empirical question. Further, given the same level of expenditure, the signaling value of CSR by incumbent firms can increase through the better choice of CSR projects and more efficient delivery compared to those by the entrants.

Notwithstanding all these arguments, most economists would like to view the mandated CSR provisions of Section 135 as an implicit tax on the companies. While this is true to a large extent, there is one key difference namely that the current CSR provisions work like a centralized tax with decentralized utilization with project implementation undertaken by private parties. Under explicit taxation there is no guarantee that the money collected by the government will be spent on CSR and not be appropriated for other uses. The implicit tax in contrast, gives companies control over the disbursement over their own funds in a directed manner, with greater

\footnotetext{
${ }^{7}$ This position clearly went against the more stringent position taken by the Parliamentary Standing Committee that without a "coercive enforcement mechanism," Section 135 will remain a "half-hearted attempt" at stepping up CSR.
} 
incentives to choose the right projects that have synergies with their lines of business operation (which the rules allow for), and greater incentives to monitor its efficient utilization. The upside of such a decentralized mechanism of social spending is that it can lead to better project delivery and reduced fund leakages that are widely perceived to be challenges for the large scale government welfare schemes.

\subsection{The Challenges}

While acknowledging the potential benefits that Section 135 can usher in strengthening the relationship between business and society in India, there are some issues and challenges that will come up during implementation of the new CSR rules which will have to be addressed through the setting up of appropriate mechanisms. First, one should be concerned about whether too much funds will be generated under the new CSR Rules leading to challenges for companies to identify appropriate projects on a sustained basis. It is important to realise that companies need to pump in 2 per cent of their net profits every year. This in turn could put a strain on the company's management to search for, select and implement additional projects, monitor its ongoing CSR activities, all of which will cumulatively build up over time both in terms of scale and scope. A quick analysis of all the BSE listed companies can help one to get a perspective of the problem.

According to the analysis, as already presented in Table 7, had the present CSR criterion been applied to listed companies in 2012, an estimated amount of Rs. 8343.9 crore would have been spent on CSR activities by these companies based on their net profit figures for FY 2012. Moving the figure to FY 2015 and taking into account that the CSR Rules apply to unlisted companies too, the amount could be well around Rs. 10,000 crore per year. Other estimates appearing in the press put the total annual CSR spending to around USD 3 billion. While, as argued above, these estimates are relatively small in relation with the total government spending on social programs, the estimates are not trivial at the company level. As shown in Table 8, our analysis reveals that the CSR spending by the median firm managing a turnover of Rs. 33 crore, is about Rs. 55 lakhs per year, and CSR projects worth this value would have to be identified annually and followed through. For large companies the issue of identifying appropriate projects on a sustained basis could be even more challenging. Companies like Reliance and ONGC, reported in Table 8, would have to spend upwards of approximately Rs. 400 crore every year towards CSR activities. This amount is likely to increase every year as the net profit of these 
companies increase. Spending of such large amounts may require large companies to have dedicated centres that identify, implement, and monitor large scale projects or a large number of smaller projects. This would entail additional costs for a company that need to be factored in evaluating the benefits from CSR. The Rules foresee this to some extent and allows companies to carry out their CSR activities through registered trusts set up by the companies or outside trusts with good track records, but the activities of these trusts would in turn become challenging and will possibly need monitoring. In this context, it is important for the government to guard against the possibility of promoters routing monies through CSR activities into trusts and organisations in which they have interest. Government will need to develop an effective way of monitoring such transactions and make legislative provisions as well.

Second, is the issue relating to the treatment of CSR kind of expenditure that companies may already be incurring. Would reclassifying them as CSR expenses meet the requirements of law? For example, can companies that are operating educational institutions or running major hospital facilities for their employees beyond what the law requires, claim the excess facilities as CSR expenditure under Section 135? Will this be allowed if such facilities are also open to nonemployees as well? Some questions have already been raised as to whether certain types of expenditure which companies have been incurring will qualify as items towards meeting the specified CSR target. In response to this, the Ministry of Corporate Affairs issued a circular dated June 18, 2014 (MCA, 2014b) specifying that "the activities undertaken in pursuance of the CSR policy must be relatable to Schedule VII of the Act and the activities mentioned in the Schedule VII must be interpreted liberally capturing the essence of the subjects enumerated therein." As stated earlier, the circular also lists certain specific types of expenditures that will count as CSR expenditure for meeting the provisions of Section 135 and those that will not. More such explanations and clarifications are likely to be made over time.

Third, is the problem of coordination of CSR projects across companies in a particular region to prevent the duplication of and overinvestment in similar types of CSR projects. This is particularly in view of the fact that the Rules recommend that companies give preference to local areas in their CSR spending. An analysis of the distribution of CSR activities by large listed companies for the year 2011 show that typically companies engage in not more than three types of activity (Figure 2), and in activities largely related to education, health and sanitation, women 
empowerment, and provision of material and financial aid which together account for 70 per cent of all CSR spending. In instances where large investments are necessary such as in hospitals and schools, smaller companies may be better off by pooling their CSR resources as it may help them to collectively undertake such projects. To achieve better coordination across companies in a particular region, formal partnerships or consortiums can be set up.

Finally, an unintended consequence of mandated annual CSR expenditure could be the cumulative build-up of social welfare programs in and around geographical regions where larger and better performing corporates are concentrated. High levels of CSR spending by such companies can benefit certain regions/states disproportionately more while other localities with sparse corporate sector activity can fall further behind. To avoid such unintended consequences at the macro level would necessitate the setting up of a coordinating agency at a Central or at least at the State level to see that CSR spending of companies are harmonized for the betterment of all.

To conclude, the new CSR provisions in India are not a case of government abrogating its responsibility to the private sector. The estimated annual amount of CSR spending by corporates judged in context of total social sector spending by the government is just around two per cent of what listed companies would have spent after applying the criteria under Section 135. Rather, the new CSR provisions should be looked at as an effort by the government to make the corporate sector play a complementary role in meeting the broader society goal of encompassing development. Under the new CSR rules, the flexibility given to the companies in choosing and monitoring the projects is likely to promote efficiency and effectiveness in project implementation without the CSR Rules coming into serious conflicts with the primary objective of shareholder value maximization of companies. Social and economic incentives seem to have been well balanced in the new CSR rules and one can hope that the corporate sector will willingly lend a helping hand to the government in contributing to the inclusive growth of the nation. 


\section{References}

Amaeshi, K. M., B.C. Adi, C. Ogbechie and O. Olufemi, 2006. "Corporate Social Responsibility in Nigeria: Western Mimicry or Indigenous Influences?” Journal of Corporate Citizenship, 24 winter, pp. 83-99.

Basu, K. and G. Palazzo, 2008. "Corporate Social Responsibility: A Process Model of Sensemaking," Academy of Management Review 33(1), pp. 122-136.

Besley, Timothy and Maitresh Ghatak, 2007. "Retailing Public Goods: The Economics of

Corporate Social Responsibility," Journal of Public Economics, Vol. 91, No. 9, p. 1645-1663.

Blowfield, Michael, and Jedrzej George Frynas: 2005. 'Editorial: Setting New Agendas -

Critical Perspectives on Corporate Social Responsibility in the Developing World,"

International Affairs 81(3), 499-513.

Bowen, HR 1953, Social Responsibilities of the Businessman, New York: Harper \& Row.

Carroll, AB 1979. "A three-dimensional conceptual model of corporate social performance, Academy of Management Review, vol. 4, pp. 497-505.

Connelly, J. T and P. Limpaphayom, 2004. "Environmental Reporting and Firm Performance:

Evidence from Thailand," Journal of Corporate Citizenship, 13, Spring: 137-49.

Davies, R., 2002. "Corporate Citizenship and Socially Responsible Investment in Asia," unpublished paper delivered at the Conference of the Association for Sustainable and Responsible Investment in Asia, Hong King, 10 June 2002. www.corporatecitizenshipasia.net/csr/csrwebassist.nsf/content/f1d2b3ar4.html Elhauge, Einer, 2005. "Sacrificing Corporate Profits in the Public Interest," New York University Law Review, Volume 80, Number 3, June, pp. 735-868.

Friedman, Milton (1970), "The Social Responsibility of Business is to Increase its Profits," The New York Times Magazine, September 13, The New York Times Company.

Frynas, J. G., 2005. "The false developmental promise of Corporate Social Responsibility: evidence from multinational oil companies," International Affairs, Volume 81, Issue 3, , May, pages 581-598.

Gangopadhyay, Shubhashis, 2012, Profiting from CSR: Mandatory spending on corporate social responsibility does not fit in a market-driven society, Business Standard, January 28. 
http://www.business-standard.com/article/opinion/shubhashis-gangopadhyay-profiting-from-csr$\underline{112012800080 \_1 . h t m l}$

Gangopadhyay, Shubhashis, 2014, CSR, out of the box: Mandated corporate social responsibility hurts shareholders, not firms, Business Standard, March 21.

http://www.business-standard.com/article/opinion/shubhashis-gangopadhyay-csr-out-of-the-box114032101233_1.html

Goenka, Harsh, 2012 Why it is a good idea to mandate corporate social responsibility, Economic Times, September 1. http://articles.economictimes.indiatimes.com/2012-09-

01/news/33535456_1_net-profit-companies-bill-crore-last-year

Heal, G., 2008, When Principles Pay: Corporate Social Responsibility and the Bottom Line, New York: Columbia University Press.

Hess, D. \& Dunfee, T.W. 2007. "The Kasky-Nike Threat to Corporate Social Reporting: Implementing a Standard of Optimal Truthful Disclosure as a Solution." Business Ethics Quarterly, vol. 17(1): 5-32.

Ho, Virginia Harper, 2013. "Beyond Regulation: A Comparative Look at State-Centric Corporate Social Responsibility and the Law in China," Vanderbilt Journal of Transnational Law, vol. 46: pp. 377-440.

http://www.vanderbilt.edu/jotl/2013/04/beyond-regulation-a-comparative-look-at-state-centriccorporate-social-responsibility-and-the-law-in-china/

Hung, Mingyi, Jing Shi and Yongxiang Wang, 2013, The Effect of Mandatory CSR Disclosure on Information Asymmetry: Evidence from a Quasi-natural Experiment in China, Working Paper, June. file:///C:/Users/js390/Downloads/3.pdf.

Karnani, Aneel, 2013, Mandatory CSR in India: A Bad Proposal, Stanford Social Innovation

Review, 16, May, 20.

http://www.ssireview.org/blog/entry/mandatory_csr_in_india_a_bad_proposal 
KPMG 2008, Corporate Social Responsibility: Towards a Sustainable Future: A White Paper, KPMG in India, KPMG.https://www.kpmg.com/in/en/services/.../whitepaper\%20on\%20csr.pdf KPMG, 2011, KPMG International Survey of Corporate Responsibility Reporting 2011, KPMG.http://www.kpmg.com/TW/zh/Documents/ccs/KPMG-international-corporateresponsibility-reporting-survey-2011.pdf

KPMG-UNEP, 2010. Carrots and Sticks-Promoting Transparency and Sustainability: An update on trends in Voluntary and Mandatory Approaches to Sustainability Reporting, KPMG Advisory NV, UNEP GRI.

Lin, L.W. 2010. “Corporate social responsibility in China: window dressing or structural change?” Journal of International Law.28(1).

LSS (2010), Standing Committee on Finance (2009-2010), Fifteenth Lok Sabha (Ministry of Corporate Affairs) The Companies Bill, 2009, Twenty-First Report, Lok Sabha Secretariat, August, New Delhi.

LSS (2012), Standing Committee on Finance (2011-2012), Fifteenth Lok Sabha (Ministry of Corporate Affairs) The Companies Bill, 2009, Fifty-Seventh Report, Lok Sabha Secretariat, , August, New Delhi.

Margolis, J. D. and J. P. Walsh, 2003, "Misery Loves Companies: Rethinking Social Initiatives by Business," Administrative Science Quarterly, 48, 268-305.

Matthew Kotchen and Jon J. Moon (2012) “Corporate Social Responsibility for Irresponsibility," The B.E. Journal of Economic Analysis \& Policy: Vol. 12: Iss. 1 (Contributions), Article 55. Matten, D., \& Moon, J. 2008. “'Implicit' and 'Explicit' CSR: A conceptual framework for a comparative understanding of CSR". Academy of Management Review, 33(2): 404-424.

MCA, 2000, Report of the Task Force on Corporate Excellence by the Ministry of Corporate Affairs, Ministry of Corporate Affairs, Government of India.

MCA, 2009, Corporate Social Responsibility Voluntary Guidelines in 2009 by the Ministry of Corporate Affairs, Government of India.

MCA, 2011, The National Voluntary Guidelines on Socio Economic and Environmental Responsibilities of Business, Ministry of Corporate Affairs, Government of India, New Delhi. 
MCA, 2013, Companies Act, 2013, Ministry of Corporate Affairs, Government of India, New Delhi. http://www.mca.gov.in/Ministry/pdf/CompaniesAct2013.pdf

MCA, 2014a, CSR Rules, 2014, Ministry of Corporate Affairs, Government of India, New Delhi. http://www.mca.gov.in/Ministry/pdf/CompaniesActNotification2_2014.pdf

MCA, 2014b, CSR Circular, 2014, Ministry of Corporate Affairs, Government of India, New Delhi. http://www.mca.gov.in/Ministry/pdf/General_Circular_21_2014.pdf

Mishra, S., \& Suar, D. (2010), Does Corporate Social Responsibility Influence Firm Performance of Indian Companies?, Journal of Business Ethics, Volume 95, Issue 4, pages 571601.

PWC (2013). Handbook on Corporate Social Responsibility in India, Price Waterhouse Coopers Private Limited.

http://www.pwc.in/assets/pdfs/publications/2013/handbook-on-corporate-social-responsibilityin-india.pdf

Reinhardt, Forest L., Robert N. Stavins, and Richard H. K. Vietor (2008), Corporate Social Responsibility Through An Economic Lens, Faculty Research Working Papers Series, Harvard Kennedy School.

Shah, Rajvi , 2013. Corporate Social Responsibility and Business Ethics, Poddar world College, Working Paper.

Steiner, G. A. (1971). Business and Society. New York: Random House

Sundar, P. (2000) Beyond Business: From Merchant Charity to Corporate Citizenship (New Delhi: Tata McGraw Hill).

van der Wees, Maret, (2009) Why firms invest in Corporate Social Responsibility: A study in the Dutch bank and insurance industry, Master Thesis, University of Matricht.

Visser, Wayne (2008), Corporate Social Responsibility in Developing Countries in Andrew Crane, Dirk Matten, Abagail McWilliams, Jeremy Moon, and Donald Siegel (eds.) The Oxford Handbook of Corporate Social Responsibility, Oxford University Press.

WBCSD (2000) Corporate Social Responsibility: Making Good Business Sense, World Business Council for Sustainable Development, Geneva, Switzerland

Zile, Caroline, 2013. “India’s Mandatory Corporate Social Responsibility Proposal: Creative Capitalism Meets Creative Regulation in the Global Market," Asian-Pacific Law \& Policy Journal Vol. 13:2, pp. 269-303. 


\section{Box 1: Corporate Social Responsibility Defined}

$\checkmark$ In a "free society," "there is one and only one social responsibility of business-to use its resources and engage in activities designed to increase its profits so long as it stays within the rules of the game, which is to say, engages in open and free competition without deception or fraud" (Friedman, 1970, emphases added)

$\checkmark \quad "$... aspect of any workable definition of corporate social responsibility is that the behavior of the firms must be voluntary" [Manne \& Wallich, 1972, p. 5, emphases added)

$\checkmark \quad$ “..the businessman's decisions and actions taken for reasons at least partially beyond the firm's direct economic or technical interest... which need to be commensurate with the company's social power" (Davis, 1960)

$\checkmark$ "The social responsibility of business encompasses the economic, legal, ethical, and discretionary expectations that society has of organizations at a given point in time" (Carroll, 1979, pp. 500).

$\checkmark$ "It refers to how business takes account of its economic, social and environmental impacts in the way it operates . maximizing the benefits and minimizing the downsides. CSR undertakings are the voluntary actions that business can take, over and above compliance with minimum legal requirements, to address both its own competitive interests and the interests of wider society..”(World Bank, 2013)

$\checkmark \quad$ "Corporate Social Responsibility is a management concept whereby companies integrate social and environmental concerns in their business operations and interactions with their stakeholders. CSR is generally understood as being the way through which a company achieves a balance of economic, environmental and social imperatives ("Triple-BottomLine- Approach"), while at the same time addressing the expectations of shareholders and stakeholders" (UNIDO

$\checkmark$ "Corporate social responsibility is the commitment of business to contribute to sustainable economic development, working with employees, their families, the local community and society at large to improve their quality of life." (WBCSD,2000).

$\checkmark$ CSR in developing countries to represent 'the formal and informal ways in which business makes a contribution to improving the governance,social, ethical, labour and environmental conditions of the developing countries in which thev operate, while 


\section{Box 2: CSR Perspectives in Selected Countries}

USA

"CSR is about taking personal responsibility for your actions and the impacts that you have on society. Companies and employees must undergo a personal transformation, re-examine their roles, their responsibilities and increase their level of accountability"

\section{THE NETHERLANDS}

"CSR is about making a leadership commitment to core values and recognizing local and cultural differences when implementing global policies. It's about companies endorsing the UN Convention on Human Rights and the ILO Rights at Work"

\section{TAIWAN}

"CSR is the contribution to the development of natural and human capital, in addition to just making a profit"

\section{THAILAND}

"CSR must be locally relevant and meaningful only if backed up action"

\section{THE PHILLIPINES}

"CSR is about business giving back to society"

\section{BRAZIL}

"CSR is about commitment to strive for the best economic development for the community, to respect workers and build their capacities, to protect the environment and to help create frameworks where ethical business can prosper"

\section{ARGENTINA}

"CSR is about a corporations ability to respond to social challenges. It starts with developing good relations with neighbors. Companies should make a strong commitment to education, worker rights, capacity building, and job security. CSR is stimulating the economic development of a community"

\section{GHANA}

"CSR is about capacity building for sustainable livelihoods. It respects cultural differences and finds the business opportunities in building the skills of employees, the community and the government"

\section{INDIA}

"urges businesses to embrace the "triple bottom-line" approach whereby its financial performance can be harmonized with the expectations of society, the environment and the many stakeholders it interfaces with in a sustainable manner (MCA, Government of India, 2011)

Source: Definitions for all countries except for India are sourced from the World Business Council for Sustainable Development (WBCSD, 2000) 


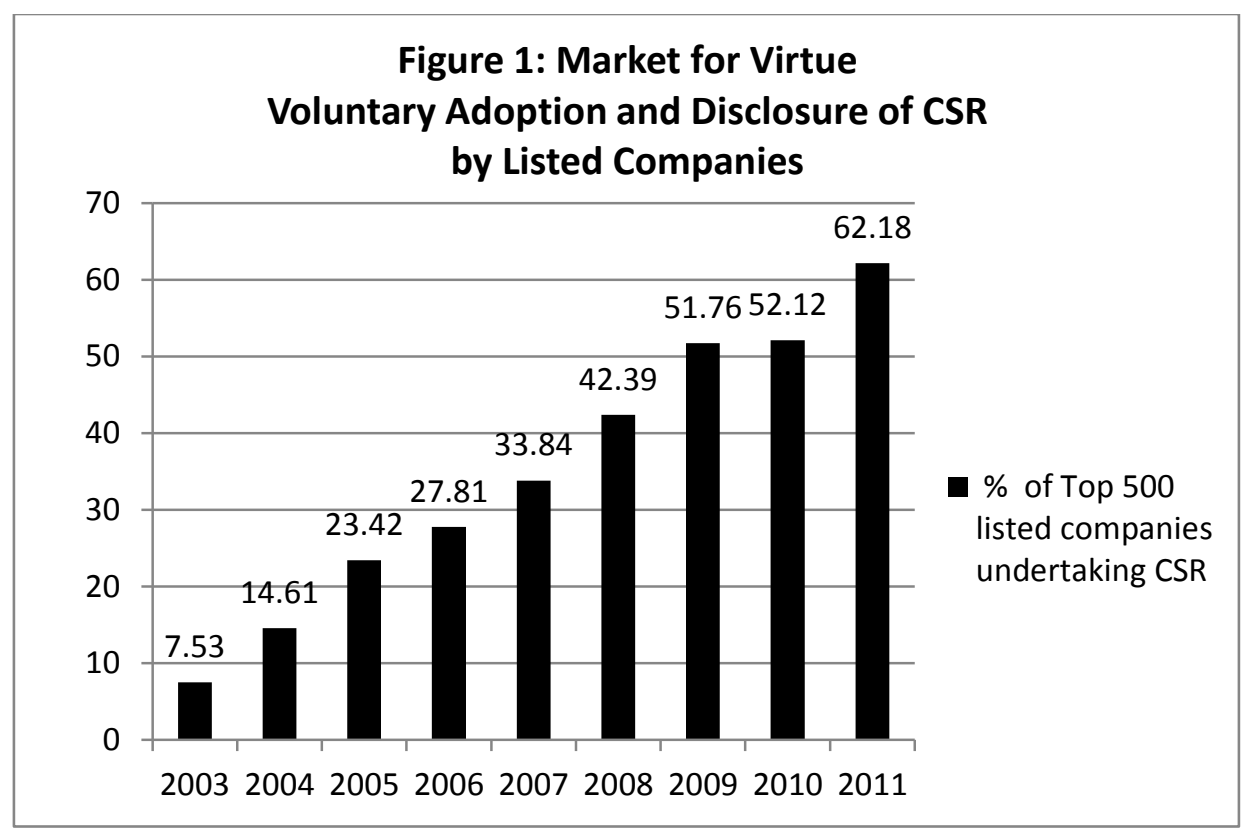

Source: Authors' computation based on top 500 listed companies in terms of market capitalization (on March $31^{\text {st }}$, 2008). Data is sourced from the Annual Reports of Companies available in the PROWESS database

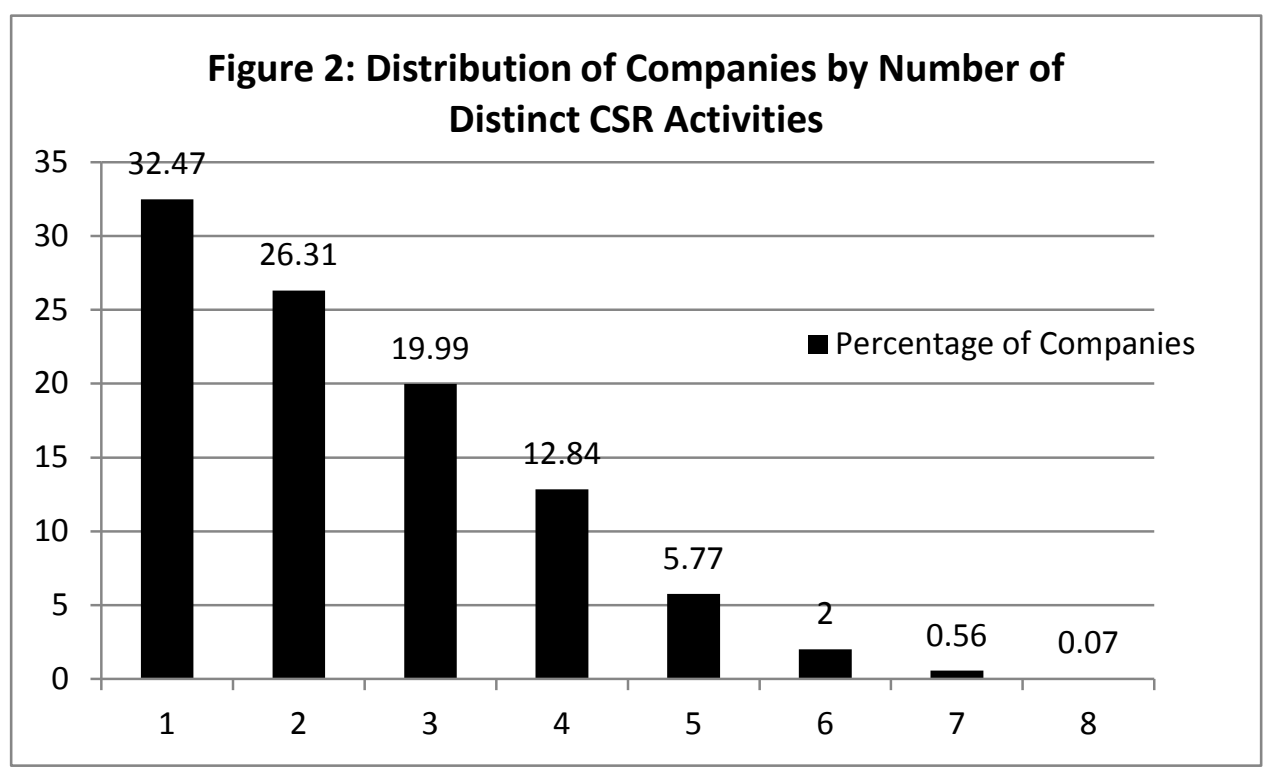




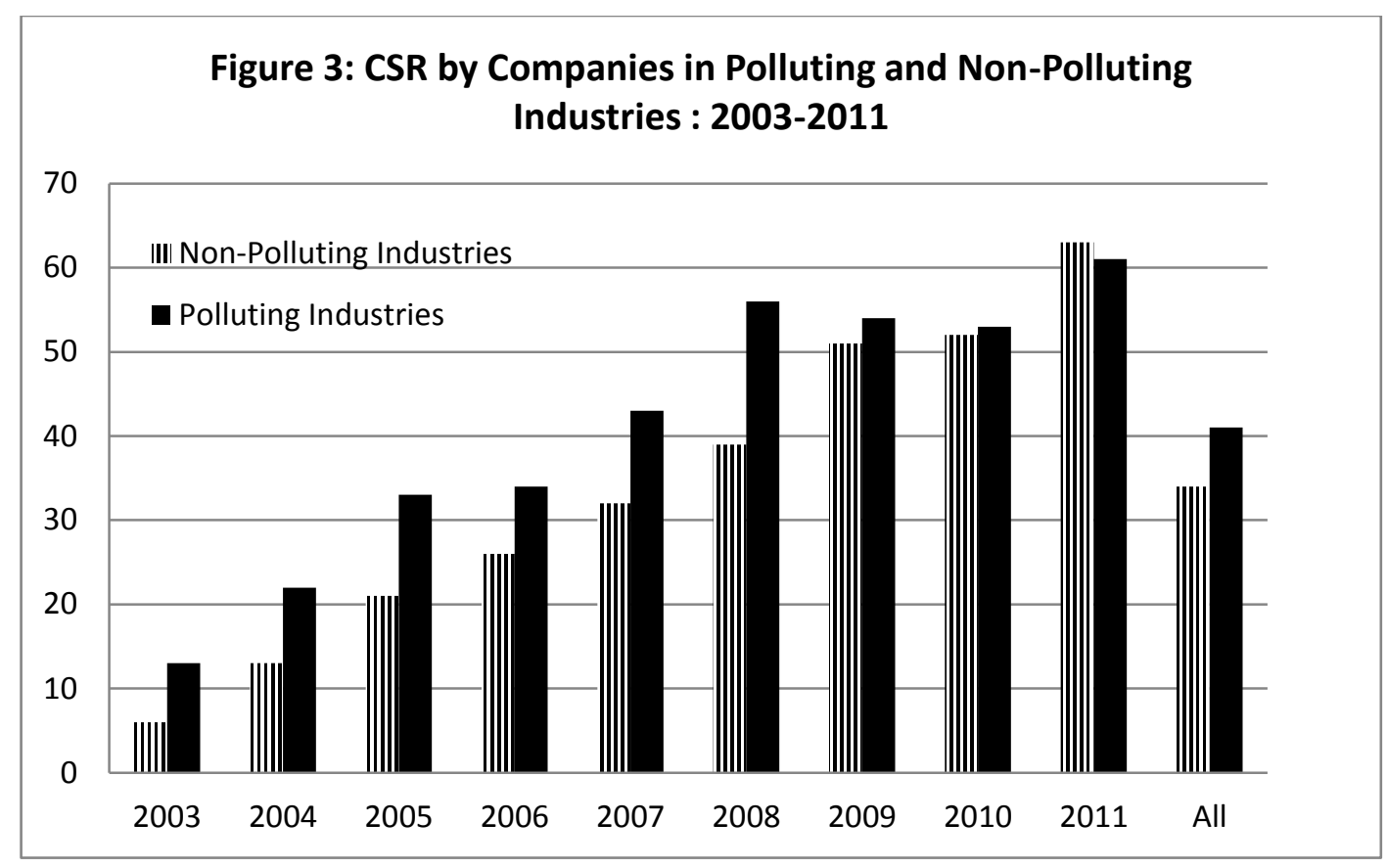

Source: Authors' computation based on top 500 listed companies in terms of market capitalization (on March $31^{\text {st }}$, 2008). Data is sourced from the Annual Reports of Companies available in the PROWESS database

Table 1: Which Companies Do CSR?

Company Characteristics and CSR

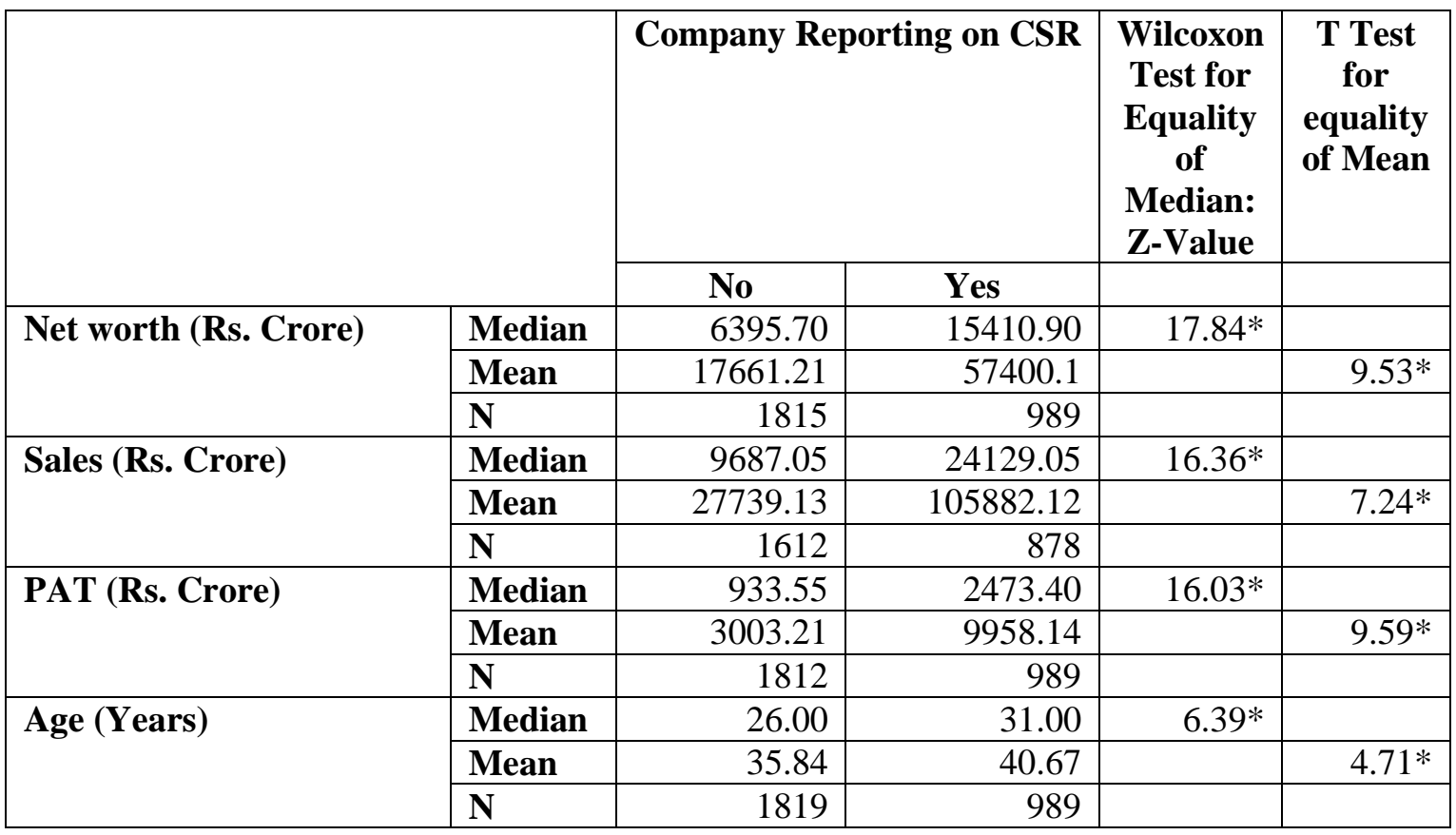

* Significant at less than 1 percent levelSource: Authors' computation based on top 500 listed companies in terms of market capitalization (on March 31 $1^{\text {st }}$,2008). Data is sourced from the Annual Reports of Companies available in the PROWESS database 
Table 2: CSR Spending of Top Companies for FY 2012-13

\begin{tabular}{|c|c|c|c|c|}
\hline Company & $\begin{array}{l}\text { Paid-up capital } \\
\text { (in crore) }\end{array}$ & $\begin{array}{l}\text { Total Turnover } \\
\text { (in crore) }\end{array}$ & $\begin{array}{l}\text { Total Profit } \\
\text { After } \\
\text { Tax(PAT) } \\
\text { (in crore) }\end{array}$ & $\begin{array}{l}\text { Total Spending on } \\
\text { CSR(in crore) } \\
\text { (approx.) }\end{array}$ \\
\hline \multicolumn{5}{|l|}{ CSR $>2 \%$ of PAT } \\
\hline Tata Motors Ltd. & 638.07 & 49,320 & 301.81 & $6.36 \%$ of $\mathrm{PAT}=19.21$ \\
\hline JP Associates & 1.18 & 13512.08 & 501.28 & $5.75 \%$ of $\mathrm{PAT}=28.82$ \\
\hline Tata Steel & 971.22 & $38,199.43$ & $5,062.97$ & $3.37 \%$ of $\mathrm{PAT}=170.76$ \\
\hline Ambuja Cement & 308.44 & 9674.94 & 1297.06 & $3.07 \%$ of PAT $=39.08$ \\
\hline Ultratech Cement & & & & $2.63 \%$ of $\mathrm{PAT}=$ \\
\hline Ranbaxy Labs & 211.457 & 6112.443 & 162.339 & $2.62 \%$ of $\mathrm{PAT}=4.27$ \\
\hline Grasim Industries & 91.78 & $5,689.58$ & $1,225.99$ & $2.13 \%$ of $\mathrm{PAT}=25.30$ \\
\hline \multicolumn{5}{|l|}{ CSR 1-2\% of PAT } \\
\hline $\mathrm{ACC}$ & 187.95 & 11130.45 & 1061.19 & $1.90 \%$ of $\mathrm{PAT}=20.16$ \\
\hline Hindustan Unilever & & & & $1.82 \%$ of $\mathrm{PAT}=$ \\
\hline IDFC & 1514.72 & 8148.42 & $1,836.00$ & $1.70 \%$. of PAT $=30.00$ \\
\hline Reliance Industries & $3,229.00$ & $371,119.00$ & $21,003.00$ & $1.71 \%$ of $\mathrm{PAT}=357.05$ \\
\hline Larsen \& Toubro & 123.08 & $61,470.86$ & $4,910.65$ & $1.49 \%$ of $\mathrm{PAT}=73.16$ \\
\hline Hindalco & 191.48 & 26056.93 & 1699.20 & $1.48 \%$ of $\mathrm{PAT}=29.79$ \\
\hline ICICI Bank & 1154.00 & 48421.00 & 8325.00 & $1.4 \%$ of $\mathrm{PAT}=116.55$ \\
\hline ITC limited & 790.18 & $41,809.82$ & $7,418.39$ & $1.1 \%$ of PAT $=82.34$ \\
\hline State Bank of India (SBI) & 684.03 & 135691.94 & 14105.32 & $1.0 \%$ of $\mathrm{PAT}=117.07$ \\
\hline Mahindra \& Mahindra & 306.99 & 40990.33 & 3352.82 & $1.0 \%$ of PAT $=33.52$ \\
\hline Sesa Goa & 86.91 & $2,554.00$ & $2,280.00$ & $1.0 \%$ of $\mathrm{PAT}=$ \\
\hline \multicolumn{5}{|l|}{ CSR $<1 \%$ of PAT } \\
\hline Axis Bank & 467.95 & $33,733.68$ & $5,179.43$ & $0.81 \%$ of $\mathrm{PAT}=42.42$ \\
\hline Asian Paints & 95.92 & $8,971.70$ & $1,050.00$ & $0.09 \%$ of $\mathrm{PAT}=0.98$ \\
\hline Bank of Baroda & 422.52 & 802069.12 & 4480.72 & $0.16 \%$ of $\mathrm{PAT}=7.00$ \\
\hline Cipla Limited & 160.58 & 8294.58 & 1507.11 & $0.5 \%$ of $\mathrm{PAT}=7.65$ \\
\hline Lupin & 8951.00 & 707239.00 & 126043.00 & $0.74 \%$ of $\mathrm{PAT}=937.00$ \\
\hline Cairn India & 1910.23 & 17524.14 & 12056.39 & $0.17 \%$ of $\mathrm{PAT}=20.86$ \\
\hline Hero Motocorp & 39.94 & $24,166.49$ & $2,118.16$ & $0.06 \%$ of $\mathrm{PAT}=1.39$ \\
\hline Kotak Mahindra Bank & 373.00 & $9,203.00$ & $1,361.00$ & $0.3 \%$ of $\mathrm{PAT}=$ \\
\hline Punjab National Bank & 353.47 & 700285.00 & 4747.52 & $0.07 \%$ of $\mathrm{PAT}=3.24$ \\
\hline Tata Power & 237.33 & $9,567.28$ & $1,024.69$ & $0.77 \%$ of $\mathrm{PAT}=7.88$ \\
\hline TCS & 295.72 & $50,656.53$ & $12,786.34$ & $0.51 \%$ of $\mathrm{PAT}=65.21$ \\
\hline
\end{tabular}

Source: Rajvi Shah, CORPORATE SOCIAL RESPONSIBILITY AND BUSINESS ETHICS, working paper

Sample: The sample consists of 29 companies out of the 50 nifty fifty companies for which CSR data exists in the annual reports for the financial year 2012-13. 
Table 3: Which Types of CSR Activities are Most Prevalent?

Distribution of Type of CSR Activities by Companies

\begin{tabular}{|c|c|c|c|}
\hline csr_type & Type of CSR Activity & Frequency & Percent \\
\hline 001 & Agriculture and irrigation & 78 & 2.56 \\
\hline 002 & Village, rural infrastructure and development & 246 & 8.06 \\
\hline 003 & Food, Drinking water, sanitation and health & 514 & 16.84 \\
\hline 004 & Education, skill development/training, and employment & 542 & 17.76 \\
\hline 005 & Waste and water management & 54 & 1.77 \\
\hline 006 & Safety and disaster management & 161 & 5.28 \\
\hline 007 & Urban development & 8 & 0.26 \\
\hline 008 & Energy/sustainability and environment (including animal and wild life) & 433 & 14.19 \\
\hline 009 & Aid (infrastructure, material aid, financial aid to NGOs) & 336 & 11.01 \\
\hline 010 & Empowerment of women/people/disability/old age care/orphanage & 302 & 9.90 \\
\hline 011 & Quality of life/Improvement of working conditions & 93 & 3.05 \\
\hline 012 & Art, sports and culture & 90 & 2.95 \\
\hline 013 & Social service and awareness & 155 & 5.08 \\
\hline 014 & Miscellaneous & 1 & 0.03 \\
\hline 000 & Not Specified & 39 & 1.28 \\
\hline
\end{tabular}

Source: Authors' computation based on top 500 listed companies in terms of market capitalization (on March $31^{\text {st }}$,

2008). Data is sourced from the Annual Reports of Companies available in the PROWESS database

Table 4: Does CSR Help Companies?

Company Performance and CSR

\begin{tabular}{|c|c|c|c|c|c|}
\hline & & \multicolumn{2}{|c|}{ Company Spending on CSR } & \multirow{2}{*}{$\begin{array}{c}\text { Wilcoxon } \\
\text { Test for } \\
\text { Equality of } \\
\text { Median: Z- } \\
\quad \text { Value } \\
\end{array}$} & \multirow{2}{*}{$\begin{array}{l}\text { T Test for } \\
\text { equality of } \\
\text { Mean }\end{array}$} \\
\hline & & No & Yes & & \\
\hline \multirow[t]{3}{*}{ ROA (\%) } & Median & 14.0 & 14.0 & 0.46 & \\
\hline & Mean & 15.09 & 16.40 & & $3.55 \mathrm{P}$ \\
\hline & $\mathbf{N}$ & 1812 & 989 & & \\
\hline \multirow[t]{3}{*}{$\operatorname{ROS}(\%)$} & Median & 21.0 & 22.1 & 0.56 & \\
\hline & Mean & 22.33 & 9.64 & & 1.23 \\
\hline & $\mathbf{N}$ & 1612 & 878 & & \\
\hline \multirow[t]{3}{*}{ PB on NSE (Times) } & Median & 2.13 & 2.53 & $4.35^{*}$ & \\
\hline & Mean & 3.27 & 3.61 & & $1.92 *$ \\
\hline & $\mathbf{N}$ & 1717 & 982 & & \\
\hline \multirow[t]{3}{*}{ PE on NSE (Times) } & Median & 13.73 & 16.50 & $4.36^{*}$ & \\
\hline & Mean & 9.60 & 19.98 & & $3.99 *$ \\
\hline & $\mathbf{N}$ & 1716 & 982 & & \\
\hline
\end{tabular}

* Significant at less than 1 percent level

Source: Authors' computation based on top 500 listed companies in terms of market capitalization (on March $31^{\text {st }}$, 2008). Data is sourced from the Annual Reports of Companies available in the PROWESS database 
Table 5A: Does CSR Pay? Relationship between CSR and Firm Value

\begin{tabular}{|l|r|r|r|r|r|}
\hline Variable & DF & $\begin{array}{r}\text { Parameter } \\
\text { Estimate }\end{array}$ & $\begin{array}{r}\text { Standard } \\
\text { Error }\end{array}$ & t Value & Pr $>|\mathbf{t}|$ \\
\hline Intercept & $\mathbf{1}$ & 3.71593 & 0.15648 & 23.75 & $<.0001$ \\
\hline CSR & $\mathbf{1}$ & 0.38964 & 0.17232 & 2.26 & 0.0238 \\
\hline Age & $\mathbf{1}$ & -0.01210 & 0.00317 & -3.81 & 0.0001 \\
\hline \multicolumn{7}{|l}{} & & & & & \\
\hline Number of Observations & & 2699 & & \\
\hline F-Value & & 8.71 & $<0.0001$ & \\
\hline
\end{tabular}

Note: OLS Regression of Performance on CSR; Dependent Variable: Market to Book Ratio (PB Ratio)

Source: Authors' computation based on top 500 listed companies in terms of market capitalization (on March $31^{\text {st }}$, 2008). Data is sourced from the Annual Reports of Companies available in the PROWESS database

Table 5B: Does CSR Pay? Relationship between CSR and Profitability

\begin{tabular}{|l|r|r|r|r|r|}
\hline \multicolumn{5}{|c|}{ Parameter Estimates } \\
\hline Variable & $\mathbf{D F}$ & $\begin{array}{r}\text { Parameter } \\
\text { Estimate }\end{array}$ & $\begin{array}{r}\text { Standard } \\
\text { Error }\end{array}$ & $\mathbf{t}$ Value & Pr $>|\mathbf{t}|$ \\
\hline Intercept & $\mathbf{1}$ & 16.06312 & $0 . .343$ & 46.86 & $<.0001$ \\
\hline Lagged CSR & $\mathbf{1}$ & 1.20334 & $0 . .396$ & 3.04 & 0.0024 \\
\hline Age & $\mathbf{1}$ & -0.02417 & 0.007074 & -3.50 & 0.0005 \\
\hline \multicolumn{7}{|l}{} & & & & \\
\hline Number of Observations & & 2699 & 2699 & \\
\hline F-Value & & 9.95 & $<0.0001$ & \\
\hline
\end{tabular}

Note: OLS Regression of Performance on CSR; Dependent Variable: Return on Assets

Source: Authors' computation based on top 500 listed companies in terms of market capitalization (on March $31^{\text {st }}$, 2008). Data is sourced from the Annual Reports of Companies available in the PROWESS database 
Table 6: Mandated CSR: Filling the Governance Gap?

\begin{tabular}{|c|c|c|c|}
\hline Indicators & FY 2012 & FY 2011 & FY 2010 \\
\hline Total BSE Listed Co. & 5138 & 5138 & 5138 \\
\hline $\begin{array}{l}\text { Total no. of qualifying companies in } \\
\text { terms of Section } 135 \text { criteria }\end{array}$ & 1372 & 1409 & 1500 \\
\hline $\begin{array}{l}\text { Total qualifying companies with } \\
\text { PAT }>0\end{array}$ & 1265 & 1312 & 1457 \\
\hline $\begin{array}{l}\text { Total PAT of qualifying companies } \\
\text { with PAT }>0 \text { (Rs. Crore) }\end{array}$ & 417198.6 & 383487.1 & 380453.1 \\
\hline $\begin{array}{l}\text { Total estimated CSR spending of } \\
\text { qualifying companies with PAT }>0 \\
\text { (Rs. Crore) }\end{array}$ & 8343.9 & 7669.7 & 7609.1 \\
\hline $\begin{array}{l}\text { Total social expenditure of } \\
\text { Central and State Government }{ }^{1}\end{array}$ & 617939.0 & 529398.0 & 446382.0 \\
\hline $\begin{array}{l}\text { CSR spending as percentage of total } \\
\text { social expenditure }\end{array}$ & 1.35 percent & 1.45 percent & 1.70 percent \\
\hline
\end{tabular}

Source: ${ }^{I}$ Economic Survey 2012-13, Government of India.

Author's computation based on top 500 listed companies in terms of market capitalization. Data is sourced from the Annual Reports of Companies for FY 2011 from the PROWESS database.

Table 7: Estimated CSR Spending by all BSE Listed Companies

\begin{tabular}{|c|c|c|c|}
\hline Indicators & FY 2012 & FY 2011 & FY 2010 \\
\hline Total BSE Listed Co. & 5138 & 5138 & 5138 \\
\hline $\begin{array}{l}\text { Total no. of qualifying companies in } \\
\text { terms of Section } 135 \text { criteria }\end{array}$ & 1372 & 1409 & 1500 \\
\hline $\begin{array}{c}\text { Total qualifying companies with } \\
\text { PAT }>0\end{array}$ & 1265 & 1312 & 1457 \\
\hline Max PAT (Rs. Crore) & $\begin{array}{c}21000.1 \\
\text { (Reliance Ind.) }\end{array}$ & $\begin{array}{l}25100.2 \\
\text { (ONGC) }\end{array}$ & $\begin{array}{c}20300.7 \\
\text { (Reliance Ind.) }\end{array}$ \\
\hline Max CSR (Rs. Crore) & 420.0 & 502.0 & 406.0 \\
\hline Min PAT (when PAT $\geq 0$ ) (Rs. Crore) & 0.3 & 0.37 & 0.14 \\
\hline Min CSR (Rs.) & 60,000 & 74,000 & 28,000 \\
\hline Median PAT (Rs. Crore) & 27.7 & 30.4 & 33 \\
\hline Median CSR (Rs.) & $55,40,000$ & $60,80,000$ & $66,10,000$ \\
\hline
\end{tabular}

Source: Author's computation based on top 500 listed companies in terms of market capitalization.

Data is sourced from the Annual Reports of Companies for FY 2011 from the PROWESS database. 